\title{
Statistical analysis of the 3D electroconductive composites based on copper and graphene
}

DOI: $10.35530 / I T .072 .02 .20207$

RALUCA MARIA AILENI

LAURA CHIRIAC

DOINA TOMA

\section{ABSTRACT - REZUMAT}

\section{Statistical analysis of the 3D electroconductive composites based on copper and graphene}

This paper presents several aspects of the multivariate analysis of electroconductive composite based on Copper (Cu) and Graphene. The analysis was developed by using the parameters (dependent and independent variables), which characterize the composite materials with electroconductive properties. The experimental samples were obtained by using $100 \%$ cotton fabrics with different structures. The goals followed through the variation of the fabric structures (e.g., plain weave, twill, panama, ribs) were to investigate if the fabric structure or ratio has or not influence on electroconductive properties of the textile materials obtained by conductive coating. The samples created were based on standard, and $3 D$ digital printing technologies, more specifically on the textile surface, have deposited conductive paste containing copper microparticles and graphene filaments. The initial coating with conductive polymeric paste based $\mathrm{Cu}$ was developed by scraping of the paste on the fabric. Previously the 3D printing advanced technology by fused deposition modeling (FDM) of the Conductive Graphene filaments was used.

Keywords: composites, textile, electroconductive, resistance, conductive, copper, microparticles, sensors, 3D, Graphene

\section{Analiza statistică a compozitelor 3D electroconductive pe bază de cupru şi grafen}

Această lucrare prezintă câteva aspecte privind analiza multivariată a compozitelor electroconductive pe bază de cupru (Cu) şi grafen. Analiza a fost dezvoltată pe baza parametrilor (variabile dependente şi independente), care caracterizează materialele compozite cu proprietăţi electroconductive. Probele experimentale au fost obţinute din materiale textile din 100\% bumbac, având diferite structuri. Variaţia structurii ţesăturii (de exemplu: pânză, diagonal, panama, rips) a avut ca scop investigarea influenţei structurii şi a raportului de legatură asupra proprietăţilor electroconductive ale materialelor textile cu acoperiri conductive. Probele au fost realizate utilizând tehnologiile clasice şi tehnologia imprimării digitale $3 D$, mai precis pe suprafaţa textilă au fost depuse paste conductive cu conţinut de microparticule de cupru şi filamente de grafen. Depunerea iniţială a pastei polimerice conductive pe bază de Cu a fost realizată prin metoda raclării. Ulterior, a fost utilizată tehnologia avansată de imprimare $3 D$ prin depunerea pe suprafaţa textilă a filamentelor topite de grafen conductiv.

Cuvinte-cheie: compozite, textil, electroconductiv, rezistenţa, conductiv, cupru, microparticule, senzori, 3D, grafen

\section{INTRODUCTION}

The conductive textile materials development is based on advanced manufacturing such as 3D printing, or advanced materials development such as ESD (electrostatic discharge) or conductive filaments graphene-based PLA (polylactic acid) matrix, and is of real interest in current research. However, the new technologies and techniques have several new parameters, and the multivariate analysis of the coated materials must analyse complex data sets. In scientific literature similar approaches can be observed in using multivariate analysis for developing fibres, yarns, or fabric models [1-4]. However, this technique is used to explain the feasibility of two-way prediction by developing models for fibre and yarn and reverse models relating yarn to fibre using multivariate. In this paper, the multivariate analysis [4-7] used to investigate the influence of the independent and dependent variables in the electroconductive textile development. In general conductive fabrics are achieved by conductive polymers (polyaniline, polypyrrole, polythiophene, poly(3,4-ethylene dioxythiophene) polystyrene sulfonate (PEDOT: PSS), or graphene [7-11]) or by distributing conductive metal micro/nanoparticles in the polymeric matrix [12-14] (e.g. PVA (polyvinyl alcohol)). Numerous scientific researches present the manufacturing of conductive materials based on graphene oxide [15-17]. The improvement of the electrical conductivity is the main subject in researches that describe the method for obtaining the conductive yarns based on carbon black nanoparticles (CB) and PVA, and the method to improve the surface conductivity by plasma-assisted attachment of functionalized carbon nanotubes on PET (poly(ethylene terephthalate)) [18, 19], by printing method. However, special attention was paid to the investigation of the physical properties of conductive materials such as metal composite, or electromagnetic shielding performance achieved through textiles with conductive and magnetic properties [20]. 
In the experimental part, we developed 20 experimental samples using cotton fabric (BBC) $100 \%$ with different structures (e.g. plain weave, twill, weft rib, warp rib, panama) with electroconductive properties based on traditional technologies for thinfilm deposition by scraping/printing and $3 \mathrm{D}$ digital printing. To achieve the experimental samples functionalized by submission of copper $(\mathrm{Cu})$ or nickel (Ni) microparticles have been used, the classic technology printing (conductive polymeric paste with $\mathrm{Cu}$ microparticles), scraping, and advanced technology for submission by the 3D digital printing based on the conductive graphene filaments.

To obtain electroconductive properties for direct printing/scraping, the polyvinyl alcohol (PVA), and metallic microparticles (Cu I, Cu II, Cu III, and Ni) were used.

The experimental part consists of two parts:

1. Development of the fabrics (20) with electroconductive properties by scraping of the conductive paste based on water, a binder (PVA) and microparticles of $\mathrm{Cu}(\mathrm{Cu}$ I microparticles with size less than $45 \mu \mathrm{m}$; $\mathrm{Cu}$ III microparticles with size less than

\begin{tabular}{|c|c|c|c|c|c|c|c|c|}
\hline \multicolumn{9}{|c|}{$\begin{array}{l}\text { EXPERIMENTAL PLAN-SAMPLES FUNCTIONALIZED BY COATING } \\
\text { WITH A CONDUCTIVE PASTE BASED ON MICROPARTICLES }\end{array}$} \\
\hline $\begin{array}{c}\text { Sample } \\
\text { no. }\end{array}$ & $\mathrm{Ni}$ & Cu I & $\mathrm{Cu}$ II & Cu III & PVA & $\mathrm{H}_{2} \mathrm{O}$ & $\operatorname{Rs}(\Omega)$ & G (S) \\
\hline 1 & & & $x$ & & $x$ & $x$ & $10^{11}$ & $10^{-11}$ \\
\hline 2 & & & $x$ & & $x$ & $x$ & $10^{11}$ & $10^{-11}$ \\
\hline 3 & & & $x$ & & $x$ & $x$ & $10^{12}$ & $10^{-12}$ \\
\hline 4 & & & $x$ & & $x$ & $x$ & $10^{9}$ & $10^{-9}$ \\
\hline 5 & & & $x$ & & $x$ & $x$ & $10^{8}$ & $10^{8}$ \\
\hline 6 & & & $x$ & & $x$ & $x$ & $10^{9}$ & $10^{9}$ \\
\hline 7 & & & $x$ & & $x$ & $x$ & $10^{9}$ & $10^{9}$ \\
\hline 8 & & $x$ & & & $x$ & $x$ & $10^{3}$ & $10^{-3}$ \\
\hline 9 & & $x$ & & & $x$ & $x$ & $10^{3}$ & $10^{-3}$ \\
\hline 10 & & $x$ & & & $x$ & $x$ & $10^{3}$ & $10^{-3}$ \\
\hline 11 & & $x$ & & & $x$ & $x$ & $10^{3}$ & $10^{-3}$ \\
\hline 12 & & $x$ & & & $x$ & $x$ & $10^{3}$ & $10^{-3}$ \\
\hline 13 & & $x$ & & & $x$ & $x$ & $10^{3}$ & $10^{-3}$ \\
\hline 14 & & $x$ & & & $x$ & $x$ & $10^{3}$ & $10^{-3}$ \\
\hline 15 & & & & $x$ & $x$ & $x$ & $10^{10}$ & $10^{-10}$ \\
\hline 16 & & & & $x$ & $x$ & $x$ & $10^{12}$ & $10^{-12}$ \\
\hline 17 & & & & $x$ & $x$ & $x$ & $10^{10}$ & $10^{-10}$ \\
\hline 18 & & & & $x$ & $x$ & $x$ & $10^{11}$ & $10^{-11}$ \\
\hline 19 & & & & $x$ & $x$ & $x$ & $10^{10}$ & $10^{-10}$ \\
\hline 20 & $x$ & & & & $x$ & $x$ & $10^{4}$ & $10^{-4}$ \\
\hline
\end{tabular}
$75 \mu \mathrm{m}$; Cu II microparticles with size in the range 14-25 $\mu \mathrm{m}$ ), and $\mathrm{Ni}$ (Ni microparticles with size less than $50 \mu \mathrm{m}$ ), followed by drying at a temperature of $23-24^{\circ} \mathrm{C}$ for 20 hours and the crosslinking for $3 \mathrm{~min}$ utes at $160^{\circ} \mathrm{C}$ for functionalization by increasing the electroconductive character (conductive, semiconductive or dissipative).

2. Deposition of the thermoplastic material (Conductive Graphene PLA) in the form of fused filaments by FDM 3D printing extruder at $200-240^{\circ} \mathrm{C}$.

Table 1 presents the surface resistance (Rs [ $\Omega]$ ) and conductance $G(S)$ for samples 1-20. For samples 1-7 it was used the same type of conductive paste based on PVA, $\mathrm{H}_{2} \mathrm{O}$ and $\mathrm{Cu}$ II microparticles, for samples 8-14 a conductive paste based on $\mathrm{Cu}$ I microparticles, PVA and $\mathrm{H}_{2} \mathrm{O}$ has been used, for samples 15-19 a conductive paste based on $\mathrm{Cu}$ III microparticles has been used, while for sample no. 20 a conductive paste based on PVA, $\mathrm{H}_{2} \mathrm{O}$, and $\mathrm{Ni}$ microparticles has been used (table 1). These 20 samples have been developed based on seven weaved structures from $100 \%$ cotton yarns (plain weave 1/1 (with cotton yarns $\mathrm{Nm} \mathrm{20/2}$ on weft), plain weave $1 / 1$ (with cotton yarns $\mathrm{Nm} \mathrm{20/3}$ on weft), twill $2 / 2$, twill $3 / 1$, panama, weft rib weave, warp rib weave).

In the case of samples 1-7, 8-14, and 15-19 changing the structure of textile support has not influenced

the electrical conductivity or surface resistance. Moreover, the changing of the conductive paste composition for sample groups 1-7, 8-14, and 15-19 has been generated an increasing or reducing the surface resistance (Rs) of the textile materials coated and in consequence and decreasing or increasing the electrical conductance $(G)$ values are presented in table 1.

For all experimental samples the physicomechanical parameters such as thickness $\delta[\mathrm{mm}]$, the mass $M$ $\left[\mathrm{g} / \mathrm{m}^{2}\right]$, the permeability to air $\mathrm{Pa}\left[\mathrm{l} / \mathrm{m}^{2} / \mathrm{s}\right]$, the surface resistance $\mathrm{Rs}[\Omega]$ have been investigated in the laboratory and these are listed in table 2 .

Figure 1 presents the topographic analysis of the surface of the textiles on the basis of the optical microscopy with the digital camera, magnification $(4 \times)$, the surface of the initial fabric 0.1 (without metallic microparticles) (figure 1,a) and the surface of the fabrics microparticle of $\mathrm{Cu} \mathrm{II,} \mathrm{Cu} \mathrm{I,} \mathrm{Cu} \mathrm{III} \mathrm{and} \mathrm{Ni}$ (figures $1, b$ and $1, e$ ).

From samples 8-15 that present a lower surface resistance the sample no. 10 was selected, that presents a proper distribution of the conductivity on the entire surface, to test the electrical conductivity using a $9 \mathrm{~V}$ battery and a $3 \mathrm{~mm}$ led and has proved that the textile surface coated by using our conductive paste developed it allows electrical the current flow. 


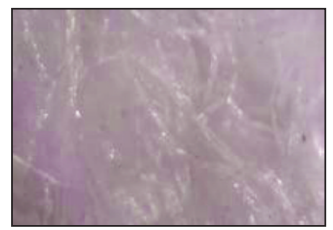

a

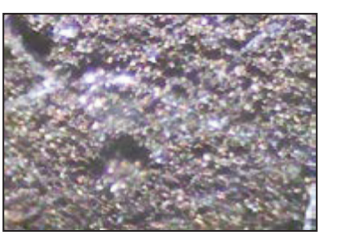

b

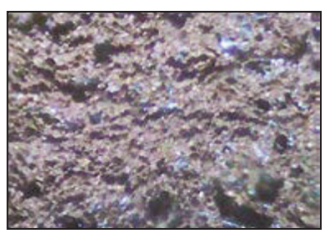

C

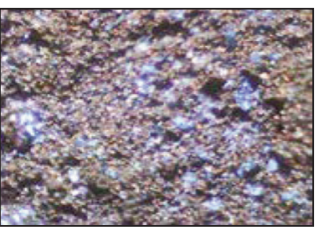

d

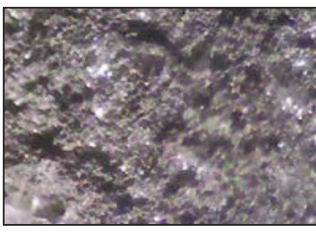

Fig. 1. Topographic analysis of the fabric surface based on optical microscopy with the digital camera: a - fabric without microparticles submitted; $b$-sample no. 3 with $\mathrm{Cu} \mathrm{II;} c$-sample no. 10 with $\mathrm{Cu}$ II; $d$-sample no. 17 with $\mathrm{Cu}$ III; e - sample no. 20 with $\mathrm{Ni}$

\begin{tabular}{|c|c|c|c|c|}
\hline \multicolumn{5}{|c|}{$\begin{array}{c}\text { Table 2 } \\
\text { PHYSICAL-MECHANICAL AND ELECTRICAL } \\
\text { PARAMETERS FOR SAMPLES 1-20 }\end{array}$} \\
\hline $\begin{array}{c}\text { Sample } \\
\text { no. }\end{array}$ & $\begin{array}{c}\text { M } \\
\left(\mathbf{g} / \mathbf{m}^{2}\right)\end{array}$ & $\begin{array}{c}\boldsymbol{\delta} \\
(\mathbf{m m})\end{array}$ & $\begin{array}{c}\text { Pa } \\
\left(\mathbf{l} / \mathbf{m}^{2} / \mathbf{s}\right)\end{array}$ & $\begin{array}{c}\text { Rs } \\
(\Omega)\end{array}$ \\
\hline 1 & 863 & 2.28 & 7.55 & $10^{11}$ \\
\hline 2 & 858 & 2.07 & 12.2 & $10^{11}$ \\
\hline 3 & 897 & 2.13 & 27.83 & $10^{12}$ \\
\hline 4 & 720 & 2.75 & 9.03 & $10^{9}$ \\
\hline 5 & 816 & 3.25 & 19.15 & $10^{8}$ \\
\hline 6 & 824 & 3.05 & 25.94 & $10^{9}$ \\
\hline 7 & 995 & 5.82 & 256.4 & $10^{9}$ \\
\hline 8 & 760 & 2.25 & 9.52 & $10^{3}$ \\
\hline 9 & 776 & 1.77 & 33.16 & $10^{3}$ \\
\hline 10 & 670 & 2.19 & 11.10 & $10^{3}$ \\
\hline 11 & 761 & 3.22 & 14.35 & $10^{3}$ \\
\hline 12 & 721 & 3.42 & 24.54 & $10^{3}$ \\
\hline 13 & 702 & 3.52 & 31.92 & $10^{3}$ \\
\hline 14 & 780 & 5.38 & 264.8 & $10^{3}$ \\
\hline 15 & 1276 & 2.68 & 101.99 & $10^{10}$ \\
\hline 16 & 925 & 2.96 & 31.22 & $10^{12}$ \\
\hline 17 & 1020 & 2.93 & 9.83 & $10^{10}$ \\
\hline 18 & 841 & 2.01 & 15.07 & $10^{11}$ \\
\hline 19 & 1033 & 3.34 & 24.74 & $10^{10}$ \\
\hline 20 & 828 & 4.42 & 109.1 & $10^{4}$ \\
\hline
\end{tabular}

After depositing the conductive paste based copper, on sample no. 10 the $3 \mathrm{D}$ conductive graphene filaments by 3D printing (figure 3 ) have been deposited using conductive filaments based Graphene. The surface obtained has been tested to investigate the

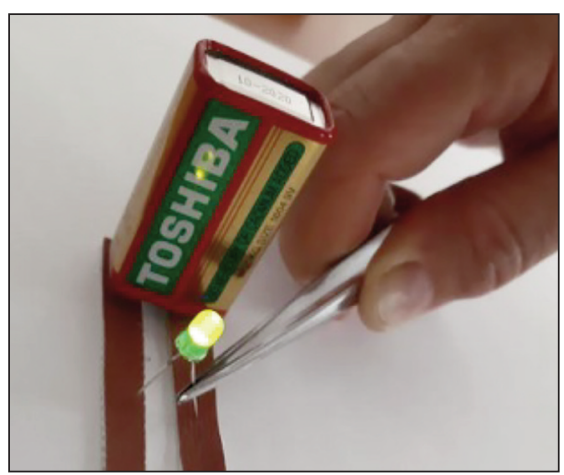

Fig. 2. Electrical conductivity test for sample 10

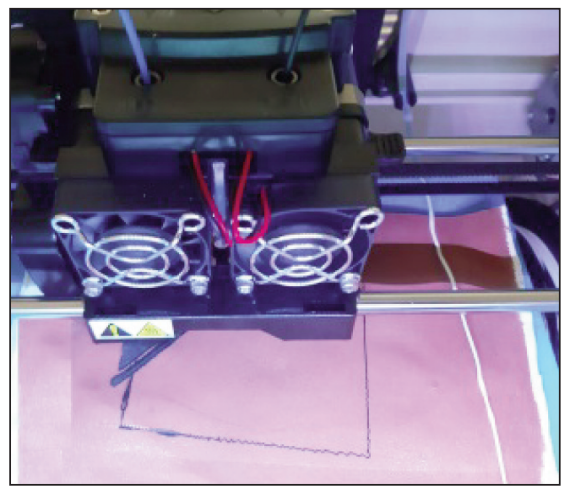

Fig. 3. 3D printing on the surface coated with paste based Cu microparticles

surface resistance, and we obtained a surface resistance of $10^{3} \Omega$, and that indicates the 3D textile composite based on conductive $\mathrm{Cu}$ paste and graphene filaments (figure 4) has a pronounced surface conductivity. It can be used for technical purposes to develop flexible sensors or electrodes.

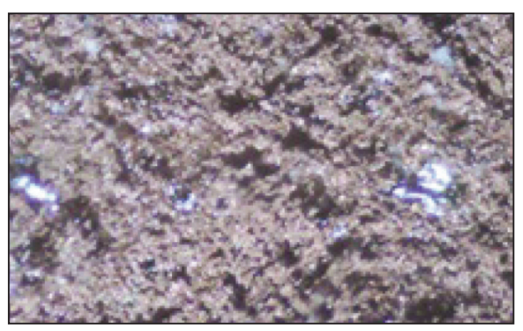

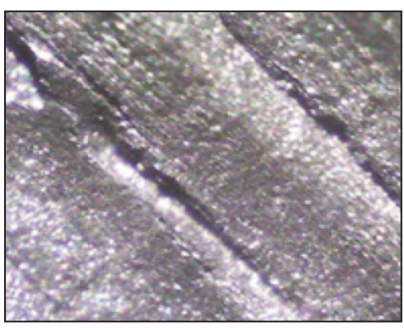

b

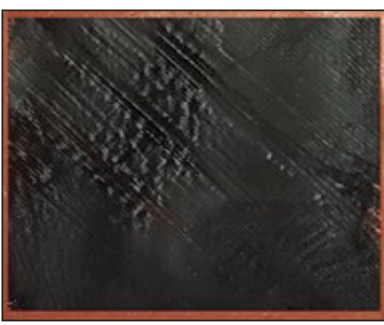

C

Fig. 4. 3D textile composite based on Cu microparticles and graphene filaments: a - Surface coated with paste based Cu microparticles (optic microscopy view using a digital camera); $b$ - Graphene filaments deposited (optic microscopy view using a digital camera); c - 3D textile composite based Cu microparticles and Graphene (digital camera view) 


\section{RESULTS AND DISCUSSIONS}

For parameters such as electrical surface resistance, the thickness $(\delta)$, air permeability $(\mathrm{Pa})$, conductance $(G)$ and mass (M) have been developed a multivariate analysis. In figures 5-9 are presented the 3D representations of the electrical resistance (Rs) in the function of the thickness $(\delta)$, mass $(M)$, air permeability $(\mathrm{Pa})$, and conductance $(\mathrm{G})$ using MATLAB software. For experimental parameters (Rs, $M, \delta, P a$, $\mathrm{G})$ it was performed an analysis of the correlation coefficient Pearson (1) between Rs and Pa, $\delta, \mathrm{M}, \mathrm{G}$ :

$$
r_{x y}=\frac{\frac{1}{n} \sum(x-\bar{x})(y-\bar{y})}{s_{x} s_{y}}
$$

where $x, y$ represent the individual values of the variables $x$ and $y ; \bar{x}, \bar{y}$ represent the arithmetic mean of all the values of $x, y ; s_{x}, s_{y}$ represents the standard deviation of all values $x$ and $y$.

$$
\begin{gathered}
r_{R_{S} P_{a}}=\left|\begin{array}{rr}
1.0000 & -0.1290 \\
-0.1290 & 1.0000
\end{array}\right| \Leftrightarrow \\
\Leftrightarrow r 12_{R_{S} P_{a}}=r 21_{R_{S} P_{a}}=-0.1290 \\
r_{R_{s} \delta}=\left|\begin{array}{rr}
1.0000 & -0.2143 \\
-0.2143 & 1.0000
\end{array}\right| \Leftrightarrow \\
\Leftrightarrow r 12_{R_{S} \delta}=r 21_{R_{S} \delta}=-0.2143 \\
r_{R_{S} M}=\left|\begin{array}{lr}
1.0000 & 0.1490 \\
0.1490 & 1.0000
\end{array}\right| \Leftrightarrow \\
\Leftrightarrow r 12_{R_{S} M}=r 21_{R_{S} M}=0.1490 \\
r_{R_{S} G}=\left|\begin{array}{rr}
1.0000 & -0.2948 \\
-0.2948 & 1.0000
\end{array}\right| \Leftrightarrow \\
\Leftrightarrow r 12_{R_{S} G}=r 21_{R_{S} G}=-0.2948
\end{gathered}
$$

Analysing the values of the correlation coefficients $r_{R_{S} P_{a}}(2), r_{R_{S} \delta}(3), r_{R_{S} M}(4)$, and $r_{R_{S} G}(5)$, it can be

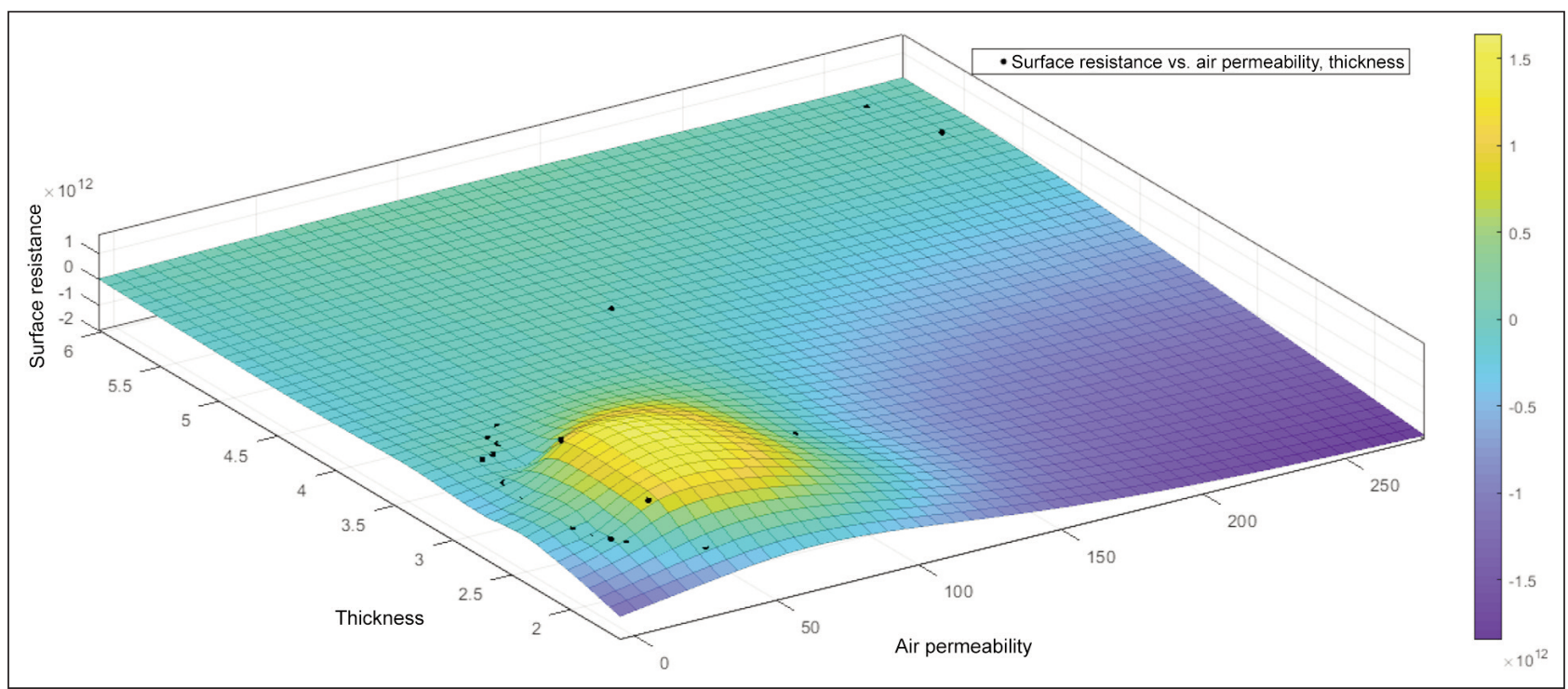

Fig. 5. 3D representation of the surface resistance according to the air permeability $(P a)$ and thickness $(\delta)(R s=f(P a, \delta))$

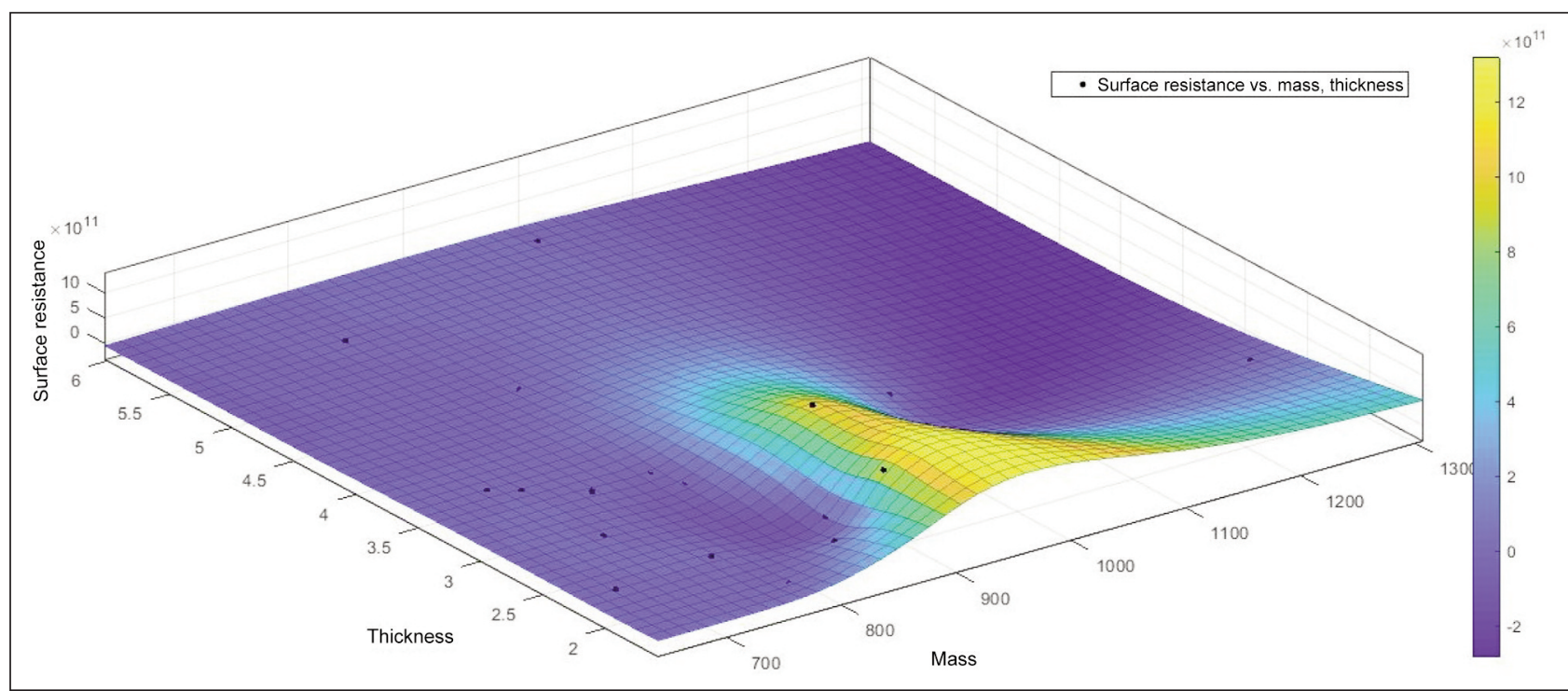

Fig. 6. 3D representation of the surface resistance $(R s)$ according to the mass $(M)$ and thickness $(\delta)(R s=f(M, \delta))$ 


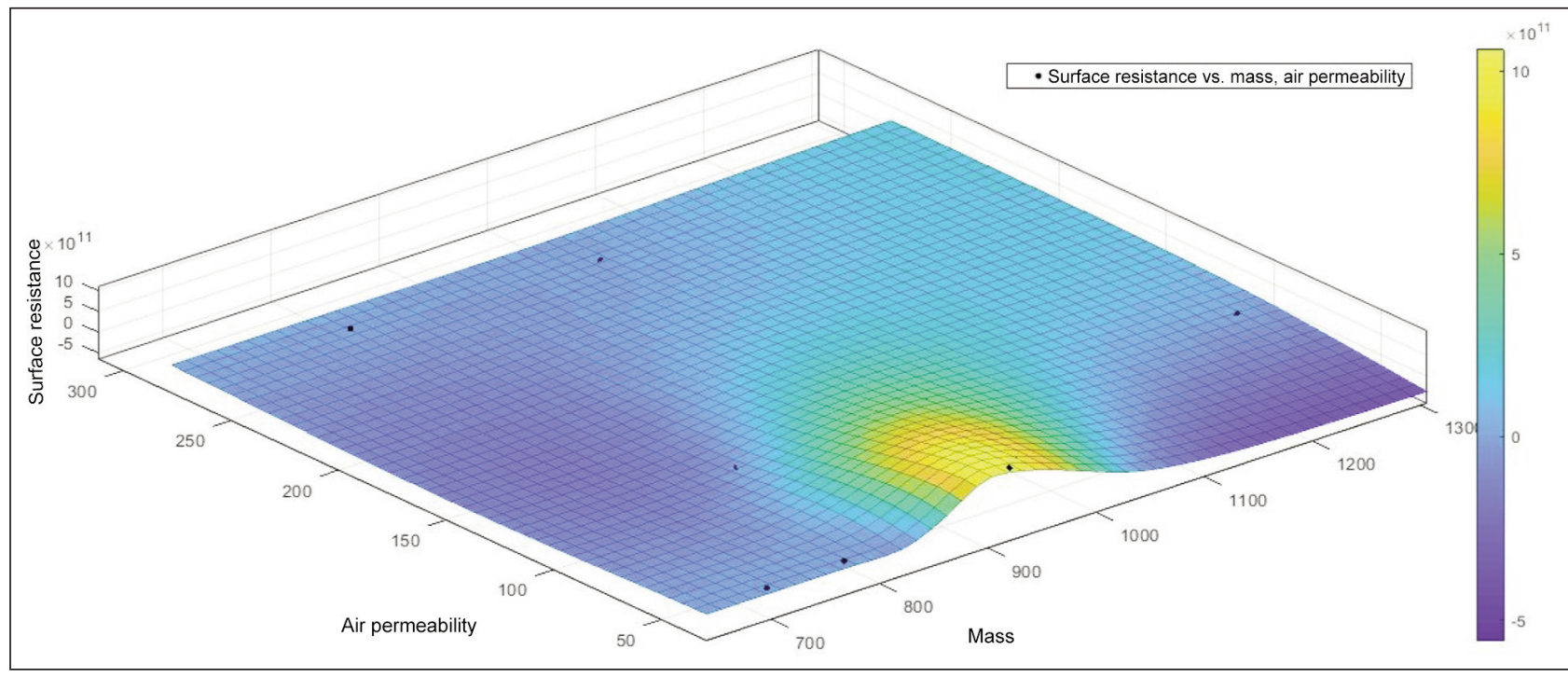

Fig. 7. 3D representation of the surface resistance $(R s)$ according to the air permeability $(P a)$ and mass $(M)(R s=f(P a, M))$

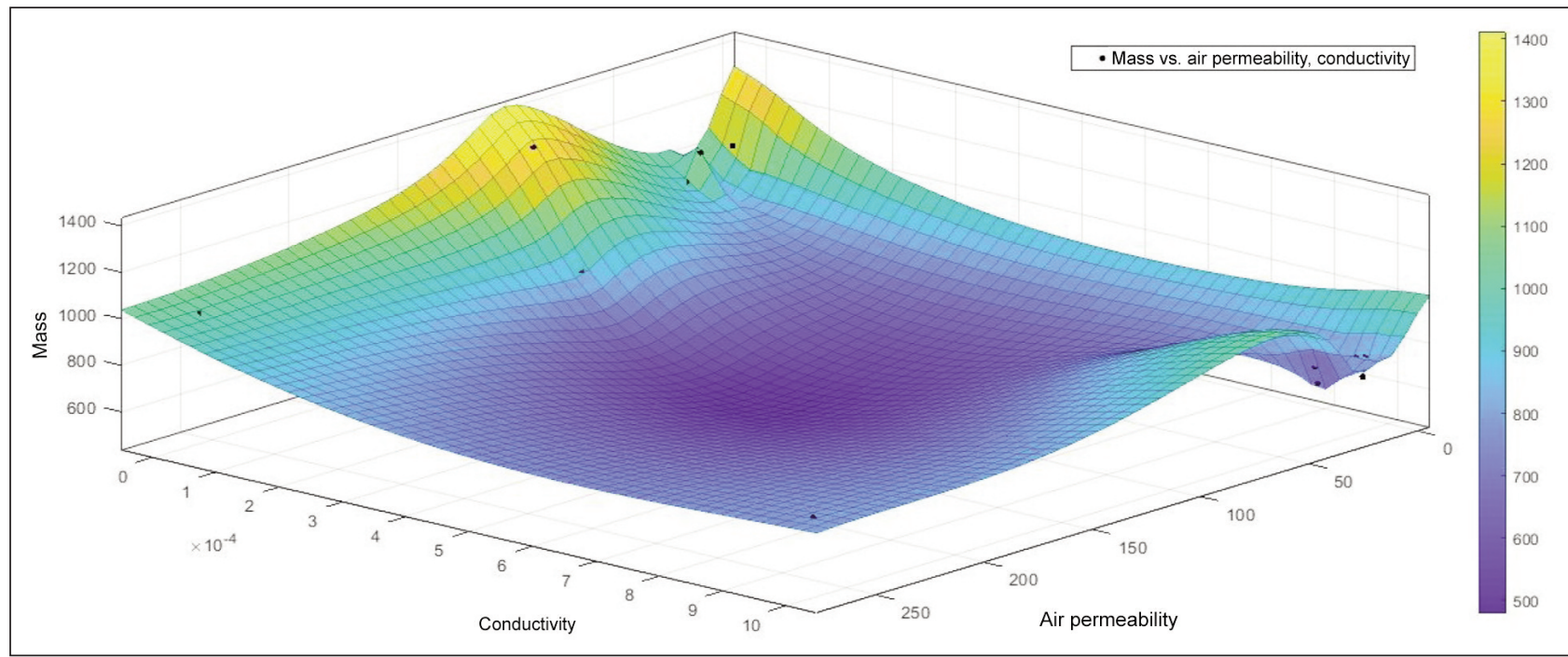

Fig. 8. 3D representation of the surface resistance (Rs) according to the thickness $(\delta)$ and conductance $(G)(R s=f(\delta, G))$

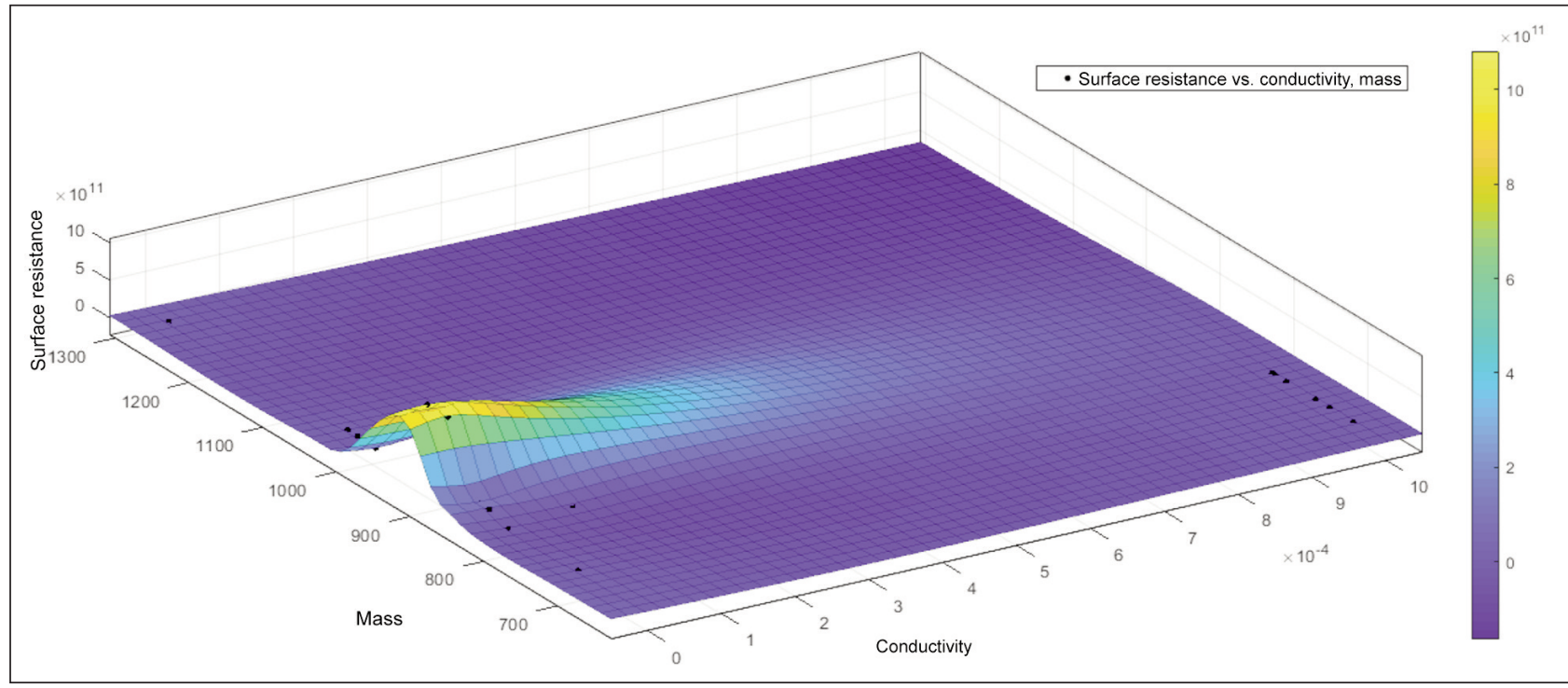

Fig. 9. 3D representation of the surface resistance $(R s)$ according to the mass $(M)$ and conductivity $(G)(R s=f(M, G))$ 
observed that between the surface resistance (Rs) and air permeability $(\mathrm{Pa})$, conductance $(\mathrm{G})$, thickness $(\delta)$ of the samples treated with a conductive paste based on $\mathrm{Cu}$ I, Cu II, Cu III, and Ni, it is a lower negative inverse proportionality relationship, and this indicates that the reduction of the surface resistance value was generate through increasing the thickness. Thickness increasing can be achieved through an additional continuous layer of conductive paste deposited, increasing the conductivity (by using conductive paste). Air permeability does not influence considerably surface resistance and conductivity because the correlation coefficient between air permeability and surface resistance is negative $(-0.1290)$, but it is very close to zero. Because the electrical resistance is inversely proportional with the electrical conductance (5), and the mass has a lower positive direct relationship with the surface resistance, this means that an increasing in the values of the mass cannot have a substantial impact on decreasing the conductivity.

Increasing of mass (due to the conductive paste) can generate the air permeability reduction, but cannot affect very strong the surface resistance and conductivity because depending on paste composition that can generate conductive or antistatic conductivity, a supplementary continuous layer of paste, with conductive/dissipative effect, deposited on a textile previously treated with the same paste does not affect the surface resistance or conductivity, but can generate the reduction of the air permeability and the increasing of mass and thickness values.

\section{CONCLUSIONS}

For samples 8-15 and 20 it is evident that the surface resistance values are specific to the conductive materials $\left(10^{1}-10^{5} \Omega\right)$ and in case of the samples $1-7$, and 15-19 the surface resistance has the values in the range $10^{8}-10^{12} \Omega$ that is specific to static dissipative materials $\left(10^{6}-10^{12} \Omega\right)$.

Based on the analysis of the Pearson correlation coefficient, it can be concluded that mass, the thickness can increase by an additional continuous layer of conductive paste deposited on the textile material. In the meantime, a continuous layer of paste with conductive/dissipative properties will affect the air permeability generating the reduction of the air permeability values. Taking into account that all positive or negative correlation coefficients are very close to zero we can conclude that the inverse or direct proportionality ratio between parameters can affect to a very small extent the values of the surface resistance or conductivity and the critical aspect that should be considered is the composition of the conductive paste that can generate the antistatic or conductive surface effect and this does not depend on textile structure.

\section{ACKNOWLEDGMENTS}

The research presented in this paper was prepared in the INCDTP laboratories. Funds support this work from MEC, National Project "Composite materials with electroconductive properties, based on 3D polymeric array for sensorial monitoring system and electromagnetic waves attenuation (3D ELECTROTEX)", Contract PN 19170101.

\section{REFERENCES}

[1] Manzoor, S., Shah, M.H., Shaheen, N., Khalique, A., Jaffar, M., Multivariate analysis of trace metals in textile effluents in relation to soil and groundwater, In: Journal of Hazardous Materials, 2006, 137, 1, 31-37

[2] Chatfield, C., Introduction to multivariate analysis, Routledge, 2018

[3] Bing, X., Wegkamp, M.H., Adaptive estimation of the rank of the coefficient matrix in high-dimensional multivariate response regression models, In: The Annals of Statistics, 2019, 47, 6, 3157-3184

[4] Fu, K.K., Padbury, R., Toprakci, O., Dirican, M., Zhang, X., Conductive textiles, In: Engineering of High-Performance Textiles, 2017, 305

[5] Zulan, L., Zhi, L., Lan, C., Sihao, C., Dayang, W., Fangyin, D., Reduced Graphene Oxide Coated Silk Fabrics with Conductive Property for Wearable Electronic Textiles Application, In: Advanced Electronic Materials, 2019, 5, 4, 1800648

[6] Trovato, V., Teblum, E., Kostikov, Y., Pedrana, A., Re, V., Nessim, G., Rosace, G., Designing of carbon nanotubes/ cotton fabric composite for e-textiles: effect of carbon nanotubes length on electroconductive properties, In: Autex 2019: Textiles at the crossroads, 2019, 1-6

[7] Method for preparing graphene-polyester nanocomposite fiber, WO2017066937A1, 2015

[8] Lee, J.H., Lee, C.S., Kim, Y.S., Song, H.J., U.S. Patent No. 9,214,559. Washington, DC: U.S. Patent and Trademark Office, US20140299475A1, 2015

[9] Graphene-based sensor, WO2017220979A1, 2016

[10] Graphene/cotton cloth flexible conducting fabric and preparing a method of graphene/cotton cloth flexible conducting fabric, CN105088749A, 2015

[11] Electrically conductive textile materials and methods for making the same, US4803096A, 1987

[12] Metallization of textile structures, EP2397577B1, 2010

[13] Method for forming interconnections between electronic devices embedded in textile fibers, Howland, C.A., U.S. Patent No. 10,448,680, Washington, DC: U.S. Patent and Trademark Office, 2019

[14] Electrically conductive textile materials and methods for making the same, US4803096A, 1987

[15] Wang, F., Xu, Z. Graphene and graphene oxide-reinforced 3D and 4D printable composites, In 3D and 4D Printing of Polymer Nanocomposite Materials, Elsevier, 2020, 259-296

[16] Weis, J.E., Charpentier, S., Kempinska, A., Graphene Research and Advances Report, December 2019 
[17] Shathi, M.A., Minzhi, C., Khoso, N.A., Rahman, T., Bidhan, B., Graphene coated textile-based, highly flexible, and a washable sports bra for human health monitoring, In: Materials \& Design, 2020, 108792

[18] Haji, A., Rahbar, R.S., Shoushtari, A.M., Plasma assisted attachment of functionalized carbon nanotubes on poly(ethylene terephthalate) fabric to improve the electrical conductivity, In: Polimery, 2015, 60, 5, 337-342

[19] Haji, A., Rahbar, R.S., Shoushtari, A.M., Improved microwave shielding behavior of carbon nanotube-coated PET fabric using plasma technology, In: Applied surface science, 2014, 311, 593-601

[20] Wang, Y., Song, Y., Qi, Q., Wang, W., Yu, D., Robustly Magnetic and Conductive Textile with High Electromagnetic Shielding Performance prepared by Synchronous Thiol-ene Click Chemistry, In: Industrial \& Engineering Chemistry Research, 2019

\section{Authors:}

RALUCA MARIA AILENI, LAURA CHIRIAC, DOINA TOMA

The National Research \& Development Institute for Textiles and Leather,

16 Lucretiu Patrascanu, 030508, Bucharest, Romania

\section{Corresponding author:}

RALUCA MARIA AILENI

e-mail: raluca.aileni@incdtp.ro 